\title{
Haematopoetic stem cell transplantation at apollo group hospitals
}

\author{
Chirag Shah
}

From International Conference on Human Genetics and 39th Annual Meeting of the Indian Society of Human Genetics (ISHG)

Ahmadabad, India. 23-25 January 2013

Hematopoietic stem cell transplantation (HSCT) is the transplantation of multipotent hematopoietic stem cells, usually derived from bone marrow, peripheral blood, or umbilical cord blood. It is a medical procedure in the fields of hematology and oncology, most often performed for patients with certain cancers of the blood or bone marrow, such as multiple myeloma or leukemia. HSCT can be divided in two types, autologous and allogenic transplant based on the source of stem cells. Autologus is when stem cells are collected from patient's own body. Allogeneic is when stem cells are collected from someone else.

Apollo group hospitals perform largest number of HSCT in private sector. HSCT requires multidisciplinary effort with team of many experts including haematologist/ oncologist, intensive care specialist, trained nursing staff, experts for venous access, infectious disease specialist, transfusion medicine expert, counsellors and many other experts.

Over 700 patients have been treated by HSCT. The majority of these patients have haematological malignancies, consisting of acute and chronic leukaemias, lymphomas, plasma cell myeloma and other haematological neoplasms. Patients with other benign blood diseases including thalassemia, sickle cell disease, aplastic anemia, Fanconi anemia, and others have also been treated. The major facility for these patients is a specially designed haematology ward with HEPA-filtered air.

The hemato-oncology department manages both adult and paediatric haematopoietic stem cell transplantation cases, where more than a hundred allogeneic and autologous transplantations are now performed every year. The full range of allogeneic transplantation is performed, with haematopoietic stem cells coming from HLA-identical

Correspondence: drchiragashah@gmail.com

Apollo Hospitals International Limited, Gandhinagar, Gujarat, India siblings, matched unrelated donors, umbilical cord blood and haploidentical donors.

Published: 21 January 2014

doi:10.1186/1755-8166-7-S1-160

Cite this article as: Shah: Haematopoetic stem cell transplantation at apollo group hospitals. Molecular Cytogenetics 2014 7(Suppl 1):160.

Submit your next manuscript to BioMed Central and take full advantage of:

- Convenient online submission

- Thorough peer review

- No space constraints or color figure charges

- Immediate publication on acceptance

- Inclusion in PubMed, CAS, Scopus and Google Scholar

- Research which is freely available for redistribution
() Biomed Central

( 2014 Shah; licensee BioMed Central Ltd. This is an Open Access article distributed under the terms of the Creative Commons Attribution License (http://creativecommons.org/licenses/by/2.0), which permits unrestricted use, distribution, and reproduction in any medium, provided the original work is properly cited. The Creative Commons Public Domain Dedication waiver (http:// creativecommons.org/publicdomain/zero/1.0/) applies to the data made available in this article, unless otherwise stated. 